\title{
Determinant Analysis of Restraint History and Length of Stay (LOS) of Patients with Schizophrenia in Aceh Mental Hospital 2018
}

\author{
Humaira $^{1}$, Irwan Saputra ${ }^{2}$ Nurjannah $^{3}$, Said Usman ${ }^{4}$ \\ 1,2,3,4 Magister Program of Public Health, Faculty of Medicine, Universitas Syiah Kuala, Indonesia \\ humairaadjalil79@gmail.com,iwanbulba@unsyiah.ac.id,nurjannah_dr@unsyiah.ac.id, \\ saidusman@unsyiah.ac.id
}

\begin{abstract}
Schizophrenia is classified as serious mental illness (SMI) due to its chronicity. Rumah Sakit Jiwa (RSJ) Aceh is the only referral mental hospital in Aceh Province. The number of inpatient visits in 2018 with a diagnosis of schizophrenia is 2,083 (96.12\%). The average length of stay is 59.76 days. The purpose of this study was to determine the relationship between history of restraint and the length of stay (LOS) of schizophrenic patients in the Aceh Mental Hospital in 2018. This study uses quantitative method. Secondary data is collected from the medical records of patients returning home in 2018. The study population was all schizophrenic patients who returned in 2018, thus using the total sampling method. The study reveals that history of restraint influences the length of stay (LOS) of schizophrenic patients in Aceh Mental Hospital in 2018. The patients with restraint history was treated longer that the patients without restraint. Restraint exacerbates the clinical symptoms of Schizophrenia and causes physical abnormalities such as wasting in the extremities so that more time is needed in treatment. To avoid the severity of clinical symptoms, extremities deformation and the length of stay, stakeholders need to take strategic steps to eradicate restraint as a method in the handling of people with mental disorders at the community level.
\end{abstract}

Keywords

Schizophrenia; restraint; length of stay (LOS).

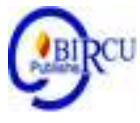

\section{Introduction}

Indonesia's basic health research in 2018 shows a significant increase in the proportion of households with mental illness schizophrenia / psychosis, which is 7 per mile, a sharp increase from 2013, at 1.7 per mile. Likewise with Aceh, the proportion of households with schizophrenia disorders increased from 2.3 per mile in 2013 to 9 per mile in 2018.

Schizophrenia is a group of psychotic disorders with distortions typical of thought processes, sometimes having the feeling that they are being controlled by outside forces, sometimes delusive understandings, impaired perception, abnormal affect integrated with real or actual situations, and autism. Schizophrenia is the most frequent psychotic disorder. Nearly $1 \%$ of the world's population suffers from schizophrenia during their lifetime. Symptoms of schizophrenia usually appear in late teens or young adults. Onset in men is usually between 15-25 years and in women between 25-35 years. Prognosis is usually worse in men compared to women. Onset after age 40 is rare (Elvira, 2013). 
Clinical symptoms of schizophrenia are generally speech disorders such as the absence of connections between ideas (loose associations), sound associations (clang associations), behavioral disorders such as stupor or rowdy anxiety, doing the opposite of what is instructed (negativism), affective disorders such as shallowness of response emotions, excessive emotions, perception disorders such as hallucinations, mind disorders like delusions (Maramis, 2009).

Clinical symptoms that arise become one for the family and surrounding communities to support schizophrenia patients.

Based on research conducted in Aceh, Samosir, Central Java, NTB, and West Java, the results showed that schizophrenia is the most mental disorder that has experienced retention ( $90 \%$ of respondents). This is because schizophrenia is at risk of committing acts of violence resulting from symptoms, requiring long-term management because it is a chronic disorder and often recurs.

The act of restraint is an attempt at binding or physical restraint on people with mental disorders and aggressive / dangerous people in the community resulting in loss of freedom to access services that can help restore the function of people with mental disorders. Prolonged restraint affects physical disability, chronic physical illness due to infection, malnutrition, and dehydration which often results in permanent disability and death. Inclusion also makes it more difficult for people with mental disorders to integrate into society due to social, economic, spiritual and cultural disabilities (Kementerian Kesehatan, 2017). Then empowerment can also be interpreted as one of the solutions for those who experience powerlessness so that they participate in feeling the results of development that they have not fully felt, this is because development is actually considered as something that weakens the position of communities (Adiwijaya, 2018).

Aceh Mental Hospital is the only referral hospital (tertiary) in Aceh Province to treat people with mental disorders. The most common diagnosis for inpatients in Aceh Mental Hospital is schizophrenia. The average length of stay in 2018 is 59.76 days. According to the guidelines for minimum hospital service standards from the Ministry of Health, the length of stay (LOS) standard for people with mental disorders is $\leq 6$ weeks or 42 days (Aceh Mental Hospital, 2009) \& (Kementrian kesehatan RI, 2008).

Schizophrenia is classified into serious mental illness (SMI) because it is chronic. People with SMI have a higher risk of hospitalization and are associated with increased medical costs and use of health care resources. In United Kingdom, this disease reaches 3.4 million or $7.2 \%$ of total beds per day (Newman, 2018).

The main impact of the increase in the length of stay (LOS) for hospitals is the use of more resources, causing a decrease in hospital revenue, especially revenue derived from JKN-BPJS payments. This is due to JKN-BPJS using the Indonesia Case Base Groups (INA $\mathrm{CBGs)}$ system in determining package rates.

\section{Research Methods}

Research conducted using quantitative methods. The data used in this study are secondary data obtained by medical records. Sampling technique by total sampling. The population of this study are the data of all inpatients with a diagnosis of schizophrenia from January to December 2018. The analysis uses univariate analysis, and bivariate analysis. Data analysis was performed using the SPSS application. 


\section{Discussion}

\subsection{Research Results}

a. Characteristics of Schizophrenic Patients in 2018

\begin{tabular}{|c|c|c|c|}
\hline Characteristics & Category & \multicolumn{2}{|c|}{ Score } \\
\hline Aged & Median & \multicolumn{2}{|c|}{ (min-max) 35 (9-93) } \\
\hline Characteristics & Category & Frequency & Percentage (\%) \\
\hline \multirow{4}{*}{ Gender } & Male & 864 & 79,4 \\
\cline { 2 - 4 } & Female & 224 & 20,6 \\
\cline { 2 - 4 } & Total & $\mathbf{1 0 8 8}$ & $\mathbf{1 0 0 , 0}$ \\
\hline \multirow{4}{*}{ Education } & Elementary & 283 & 26,0 \\
\cline { 2 - 4 } & Junior High & 215 & 19,8 \\
\cline { 2 - 4 } & Senior High & 417 & 38,3 \\
\cline { 2 - 4 } & Diploma & 31 & 2,8 \\
\cline { 2 - 4 } & Bachelor & 22 & 2,0 \\
\cline { 2 - 4 } & No Information & 120 & 11,0 \\
\cline { 2 - 4 } & Total & $\mathbf{1 0 8 8}$ & $\mathbf{1 0 0 , 0}$ \\
\hline
\end{tabular}

\begin{tabular}{|c|c|c|c|}
\hline Characteristics & Category & Frequency & Percentage (\%) \\
\hline \multirow{2}{*}{$\begin{array}{c}\text { Restraint } \\
\text { History }\end{array}$} & Yes & 87 & 8 \\
\cline { 2 - 4 } & No & 1001 & 92 \\
\cline { 2 - 4 } & Total & $\mathbf{1 0 8 8}$ & $\mathbf{1 0 0 , 0}$ \\
\hline
\end{tabular}

b. The Difference Test between Restraint History and the Length of Stay on Schizophrenia Patients

\begin{tabular}{|l|l|l|l|}
\hline \multicolumn{2}{|c|}{ Variables } & \multicolumn{2}{c|}{ The length of stay } \\
\cline { 3 - 4 } \multicolumn{2}{|c|}{} & Mean Rank & P-Value \\
\hline Restraint History & Yes & 664,06 & 0,000 \\
\hline & No & 534,11 & \\
\hline
\end{tabular}

From the results of testing the restraint history on the length of stay obtained information that the value of Asymp sig. is $0.000(<0.05)$, it can be concluded that there is a difference between the restraint history and not for the the length of stay.

\subsection{Discussion}

\section{a. Frequency Distribution}

The results showed that schizophrenia patients undergoing treatment at Aceh Mental Hospital in 2018 were male, amounting to $79.4 \%$, the remaining $20.6 \%$ were women. In aspect of education, patients with secondary education were $58.8 \%$, low education were $37.0 \%$ and high education were $4.9 \%$. Patients with a restraint history were $8 \%$ and no restraint history were $92 \%$.

The prevalence of schizophrenia between male and female is the same but there are differences in the onset and course of the disease in which male have an earlier onset than female. 
The treatment room at Aceh Mental Hospital often accommodates more male patients than female. There are only 3 rooms for female patients in 15 treatment rooms. This is consistent with the results of research that schizophrenia patients are more male than female sex (Saddock, 2010).

The number of schizophrenic patients who received primary and secondary education reached $45.8 \%$ and another $11 \%$ were included in the other categories (not attending school or not completing their education level). Education is related to the patient's knowledge, especially regarding the impact of undergoing treatment in a hospital for a long period of time.

In a study conducted by Jacobs et al (2015), the results showed that the number of male patients was higher than female patients. Likewise, research conducted in Japan in 2015 showed that most patients with mental disorders with a secondary education level.

Patients who have experienced fewer retention than those without none, this result is in accordance with Jacob's research (2015) that patients who have been restraint accounted for $20 \%$ and those who had not been put in pairs accounted for $80 \%$ (Jacobs, 2015).

\subsection{The Relationship between the Lengths of Stay (LOS) on Schizophrenia Patients and Restraint History}

The results of the study showed that patients with schizophrenia who had a restraint history would undergo treatment longer than patients with no restraint history.

The results of this study are in accordance with research conducted by Jacob (2015) that schizophrenic patients who have a restraint history have the length of stay (LOS) 19 days longer than those who are not restraint (Jacobs, 2015).

The Restraint is aggravate the schizophrenia that has been suffered. Many negative effects caused by sufferers experience trauma, feel vengeful and abandoned by the family, low self-esteem and despair. Over time there will be depression and suicidal thoughts. This of course complicates the treatment process both done in mental hospitals and when patients are at home. Treatment is not very meaningful, which allows the use of more medichines and the dose must be higher than what is commonly used.

Besides that, it also creates physical abnormalities from schizophrenics, especially if done for a long time. The most common physical abnormality is atrophy or reduction in the motion of the hands and feet. This of course will require a longer treatment process.

These results are in accordance with research conducted by the Community Psychiatry Division of Medicine Faculty, University of Indonesia, Cipto Mangunkusumo Hospital, Jakarta about the effects of restraint in the period 2006-2007. After careful examination, the muscles from the hips to the legs shrink because they have not been used for a long time. This impact is found in patients who have been restraint up for ten years. Restraint victims will get angry and vent their emotions out of normal. In the end the anger will subside, sufferers feel tired and choose silence. The situation has indeed become calm, but it is precisely in this state of silence that treatment is increasingly difficult to do because the zest of life starts to be less (Idaiani, 2015).

When viewed from the reasons for mounting, the results obtained as contained in a study conducted by Ibrahim Puteh et al (2011) found that $79.7 \%$ of the main reasons were aggressive behavior of patients and the remaining $20.3 \%$ due to concerns about patient safety and welfare because wandering around. The decision to carry out the restraint is in the family of the patient around $86.4 \%$ and the remaining cases in the amounting to $13.6 \%$ the decision of the retention is made by community leaders. 
The above concerns will make it difficult for families to pick up patients home from Aceh Mental Hospital even though they have recovered clinically. Sometimes also accompanied by rejection from the community against

Based on the results of research conducted by Rosdina that the family's inability to modify the social environment, residence and surrounding areas, family belief in the healing of schizophrenics is very low, families also do not have much time to care for patients so that they are left at home by locking the door from outside.

Restraint history is a determinant of LOS in schizophrenia patients in Aceh Mental Hospital. Restraint history contributed to a longer length of stay. This certainly has an impact on mental hospital income. Nearly $100 \%$ of patients use insurance both sourced from the center and the region where filing the cost of treatment is calculated based on INA CBGs in the form of a package. Therefore, the longer the patient stays in the hospital, the hospital's income decreases.

Aceh Mental Hospital can minimize the length of stay through the intervention of the determinant variables above, including by providing understanding to the community through education both directly during the pick-up program or integration program to the regency/city. Educational programs can also be done through mass media so that the practice of inclusion of schizophrenia patients in the community needs to be eliminated. In addition, Aceh Mental Hospital needs to strive to provide optimal treatment to prevent recurrence so that families and the surrounding community do not have a reason to restraint.

\section{Conclusion}

Restraint history affected the Length of Stay (LOS) of schizophrenia patients in Aceh Mental Hospitals. Patients with a restraint history have a longer Length of Stay compared to patients with no restraint history. It is suggest that the management of Aceh Mental Hospital needs to work on optimizing the Length of Stay (LOS) of patients with various interventions, namely by educating the public to better understand and care for the handling of schizophrenia patients properly and coordinating with Public Health Center as a primary health care center in alleviating restraint practices for people with mental disorders.

\section{References}

Adiwijaya, S., et al. (2018). Empowerment Pattern for Thalasemi Patients in Dr. Soetomo Hospital Surabaya (Study of the Association of Parents with Thalassemia Indonesia, Surabaya). Budapest International Research and Critics Institute-Journal (BIRCIJournal), 1(4): 289-298.

Elvira SD, G H. (2013). Buku Ajar Psikiatri. Jakarta: Badan Penerbit Fakultas Kedokteran Universitas Indonesia.

Idaiani S. (2015). Faktor Yang Paling Dominan Terhadap Pemasungan Orang Dengan Gangguan Jiwa Di Indonesia (Factors Contributing to Shackling Practice of Psychotic People in Indonesia).

Jacobs R, Gutacker N, Mason A, et al. (2015). Determinants of hospital length of stay for people with serious mental illness in England and implications for payment systems: A regression analysis. BMC Health Serv Res;15(1):1-16. Doi:10.1186/s12913-015-110769

Nakanishi M, Niimura J, Tanoue M, Yamamura M, Hirata T, Asukai N. (2015). Association between length of hospital stay and implementation of discharge planning in acute psychiatric inpatients in Japan. Int J Ment Health Syst. 9(1). Doi:10.1186/s13033-015- 
0015-Maramis WF. Catatan Ilmu Kedokteran Jiwa. 2nd ed. Airlangga University Press; 2009.

Newman L, Harris V, Evans LJ, Beck A. (2018). Factors Associated with Length of Stay in Psychiatric Inpatient Services in London, UK. Psychiatr Q. 2018;89(1):33-43. doi:10.1007/s11126-017-9498-7Kementerian Kesehatan. Riset Kesehatan Dasar 2018.

Kementerian Kesehatan. Peraturan Menteri Kesehatan Republik Indonesia No. 54 Tahun 2017 Tentang Penanggulangan Pemasungan Orang Dengan Gangguan Jiwa. 1-14. https://www.persi.or.id/images/regulasi/permenkes/pmk542017.pdf.

Rumah Sakit Jiwa Aceh. (2019) Rumah Sakit Jiwa Aceh Tahun 2018.

Kementrian kesehatan RI. (2008). Keputusan Menteri Kesehatan no129 tahun 2008 tentang standar pelayanan minimal rumah sakit.

Saddock BJ. (2010). Sinopsis Psikiati : Ilmu Pengetahuan Perilaku Psikiatri Klinis.

Puteh I, Marthoenis M, Minas H. (2011). Aceh Free Restraint: Releasing the mentally ill from physical restraint. Int J Ment Health Syst. 5:1-5. Doi:10.1186/1752-4458-5-10

Rosdiana R. (2018). Identifikasi Peran Keluarga Penderita dalam Upaya Penanganan Gangguan Jiwa Skizofrenia. Media Kesehat Masy Indones. 14(2):174. doi:10.30597/mkmi.v14i2.3787 